Vol 41 (2016) No 184 267-289

\title{
Reforming Higher Education Finance in Turkey: The Alumni - Crowdfunded Student Debt Fund "A-CSDF" Model
}

\section{Semen Son-Turan ${ }^{1}$}

\begin{abstract}
This study presents an innovative and sustainable system for mobilizing Turkish university alumni to contribute to a crowdfunded pool repackaged as a student debt instrument with an elaborate performance tracking tool, various payoff structures and income-contingent repayment schedules. The ultimate aim is to offer a remedy for the conspicuous global shortage of alternative finance sources and various forms of aid to higher education students in the short-term, and, through enabling equitable and egalitarian access to quality higher education, transforming society and enhancing economic development in the longer-term. The model rests upon a six-dimensional framework and its infrastructure is facilitated by a newly emerged form of digitally enhanced financing, "crowdfunding". The research method involves content analysis and data triangulation for validation purposes to determine the sub-themes surrounding the higher education problem in Turkey. The theme-driven keywords are searched for on Turkey's first original social network, Eksi Sozluk, to uncover trends and biases towards student loans, debt repayment and associated concepts. Subsequently, the same keywords are utilized in a Google Trends search volume analysis, and are finally validated by a focus group discussion. The theoretical framework to explain students' attitudes towards borrowing and loan repayment and the motivation behind alumni and charitable giving, rests mainly on behavioral economics. The A-CDSF Model uniquely addresses the higher education finance problem in Turkey and offers an easily implementable original solution for institutions and policy makers.
\end{abstract}

Keywords

DOI: 10.15390/EB.2016.6137

\section{Introduction}

This study revolves around several critical themes associated with higher education financing, a global phenomenon for policy makers, institutions of higher education, students and households, as well as student loan providers. Especially in hard times of fiscal austerity and the lingering credit crunch following the global financial crisis of 2008, competition for limited scholarships has become fierce and students with no or low family support, who can't find any kind of scholarship, are faced

${ }^{1}$ MEF University, Faculty of Economics, Administrative and Social Sciences, Business Administration, Turkey, sons@mef.edu.tr 
with the burden of managing and paying back their student debt. In the United States, student debt surpassed USD 1.1 trillion in 2014 (Mezza \& Sommer, 2015), while default rates among student loan borrowers rose to their highest levels in twenty years (Looney \& Yannelis, 2015). The situation is not bright for Turkey either with a total of almost one million debtors whose overdue student debt has been turned over to collection agencies (YURTKUR, 2014).

Following the constitutional amendment in 1984, the first private non-profit university ("foundation university"), Bilkent University, was established. Since then, the number of foundation universities in Turkey has reached 72, next to 104 state universities as of March 2014. However, only $7 \%$ of students in Turkey are enrolled at foundation universities (YÖK, 2015). Erguvan (2013), attributes the expansion of foundation universities mainly to the inability of public universities in updating their academic and organizational policies to meet global demand, and to the fact that due their centrally governed mechanism they have for long been restricted by legislation and funding constraints. While the spread of foundation universities may have helped raise the quality of Turkish education through competitive advantages, these institutions are still relatively restricted in terms of geographical reach. As an additional factor of burden, the metropolitan cities of Istanbul, Izmir and Ankara, where these higher education institutions are concentrated, have a relatively high cost of living. Next to the minimum tuition rate, referred to as "student contributions", charged by public universities making them essentially "free", foundation universities' annual tuition rates range from TL 12.000 to TL 57.000 (Kuburlu, 2014).

The Confederation of Turkish Trade Unions reports the 2015 starvation threshold in Turkey (defined as the minimum amount a family of four needs to spend in order to consume healthy, balanced and sufficient nutrients) and the poverty line (which includes the former threshold and the costs for the provision of all necessary living expenses), to be TL 1.344,58 and TL 4.379,73, respectively (TEKSIF, 2015). In Turkey, with 16,3\% of population below the poverty line (Dogan, 2014), and, an increasing tertiary gross enrollment rate of $61 \%, 69 \%$ and $79 \%$ over the period from 2011 to 2013 (Worldbank, 2015), students from various socio-economic levels need to seek some form of funding. According to the Turkish Statistical Insititute, it pays off to have a tertiary degree in Turkey. Contingent upon finding employment, the mean annual income has the potential to be consistently higher for those with a post-secondary degree, as has been observed during 2006-2014 (TÜİK, 2015).

In the global perspective, where government and public spending no longer suffice, alumni and other private sponsors step in to contribute to higher education financing. For instance in the USA, the second largest portion of university donations come from alumni. However, even there, alumni giving rates are declining due to various reasons (White, 2015). Compounding the situation in Turkey as we explore in the proceeding sections, there is no visible systematic alumni giving culture.

When the issue of funding is central to a study as it is in the present one, an explanation of the providers, the receivers, the intermediary and the conditions of the market that brings them together deems necessary. This paper argues that, in Turkey an untapped and potentially huge source of funding for university students are alumni. Thus, private student loans could be made available through alumni as lenders. The main instrument then, is a fixed income instrument that provides a pre-determined and regular stream of cash flows to the debtor and an affordable loan to the student, who will start repaying principal and interest according to an income-contingent schedule. This means that the student's repayments are conditional on a) the attainment of employment, and b) having reached a certain income threshold.

Any financial transaction requires intermediation. Traditional financial intermediaries, that bring lenders and borrowers together, are banks or investment houses. However, technology evolves at flying speed and the past few years have witnessed an influx of alternative financing venues marked by lower barriers to entry. These conditions are especially suited for individuals or small entrepreneurs who can't fulfill the rigid requirements of a more structured financial instrument like, for instance, a bank credit. This new alternative financing source is called "crowdfunding". 
Crowdfunding relies on relatively modest contributions of a large number of people that are virally mobilized through an online donation-or investment-based model with the aim of supporting a cause, business or project. Debt-based crowdfunding, also known as "peer-to-peer lending", involves the creation of a loan instrument through the same logic. The Alumni Crowdfunded Student Debt Fund "A-CSDF" Model includes a traditional financing instrument that sources money from alumni through a crowdfunding platform, which operates as both a financial market and a social networking site, pooling money together and redistributes it to students under certain conditions and terms of repayment. Contributing alumni, similar to the returns of a traditional fixed income instrument, may receive monthly interest payments and the principal upon maturity.

The preceding paragraph explains briefly how the model works. On the other hand, the theoretical framework, or, why the model should work, is based on behavioral economic theory explaining cognitive biases of alumni and students, that are addressed and circumvented by the ACSDF Model.

Economists regard student loan default as a potential factor that may trigger the next economic crisis (Stiglitz, 2013). As such, it is a critical issue that diffuses to all levels of society. In this regard, the significance of the A-CSDF Model, if successfully implemented and backed by regulatory policies, is that it has the potential to be a remedy for (1) the tightening credit crisis by offering alternative sources of funding for students and (2) the rising student debt default rates through structuring meaningful income-contingent repayment plans and financially educating and motivating the borrowing student to pay back when the time comes. Thereby, the model becomes a selfreinforcing system that adds value to human capital. If popularized, the A-CSDF Model may be instrumental in transforming the Turkish society and increase the country's economic welfare.

This paper aims at outlining the higher education finance problem in Turkey, presenting a sustainable system that addresses all relevant aspects to the problem through the introduction of the A-CSDF Model.

Following this introduction, the author, presents the background of the central theme through an interdisciplinary literature review and secondary analysis, and then develops the research questions tying them to the theoretical framework. The research methodology involves online content analysis through keywords that are generated as a result of the attainment of a thematic list of problem categories associated with higher education finance in Turkey. Data triangulation is achieved through the usage of two online sources of data and a focus group discussion. One of the online sources is Turkey's first original social network, a collaborative hypertext dictionary called "Eksi Sozluk" (www.eksisozluk.com). The other source is Google Trends (www.google.com/trends/), which provides keyword search data as an index that represents search intensity. Online data sources are very powerful and relatively unbiased, as opposed to interviews or questionnaires, to gauge user sentiment. Next to traditional offline sources, online data sources, like collaborative forums or search data, are particularly important in sentiment studies involving Millenials (individuals born between 1981-2000), as this group of people is digitally native, living in continuous connectivity. Subsequent to the research methodology, the A-CSDF Model is introduced followed by a discussion of the significance and implications of this research. The paper concludes along with suggestions for future study. 


\section{Background and Literature Review}

The background of this study is related to observations, facts and literature review associated with three broad areas: (1) higher education in Turkey, (2) the student loan market and repayment issues, and (3) alumni and voluntary giving.

\section{Higher Education in Turkey}

Turkey has one of the highest earnings premiums among OECD countries. In 2012, adults with a tertiary education earned $91 \%$ more on average than an adult with an upper secondary education, compared with the OECD average of 59\%. While employment rates for adults in Turkey are highest for individuals with tertiary education, the 2012 employment rate for individuals with tertiary education was $76 \%$, below the OECD average of $84 \%$ (OECD, 2014a). In recent years, the subsidy allocated to public institutions of higher education through the government's line item budget has experienced a relative decrease. In 2004, this subsidy amounted to 0,93\% of GNP or USD 1.311 per student, an amount significantly lower than the OECD average of USD 7.023, affecting quality and access to education (Mizikaci, 2006). The current situation has not changed much and investment in education is still below average: Turkey spends $4 \%$ of its GDP on educational institutions at all educational levels, compared with an average of $6 \%$ for OECD countries.

\section{The Student Loan Market}

The worst scenario for students is leaving school with debt and no degree. In the USA, nearly seven million students with debt are reported to not having made a payment in a year and the average repayment rate (students, who were actively paying off loans) among almost 1.200 for-profit schools was, with $61 \%$, the lowest of any sector (Fuller \& Berkin, 2015).

Globally speaking, there are two broad types of student loans: fixed repayment (also referred to as mortgage-style) loans and income-contingent loans. In a fixed repayment loan system, students have an obligation to repay the loan within a fixed period, whatever their financial situation after their studies may be. In income-contingent loan systems, repayment is contingent upon the borrower's income reaching a certain threshold, and includes a potential debt forgiveness. This type of repayment arrangement considers the ability of the graduate to repay their loan. According to the OECD (OECD, 2014b), the prevalence of income-contingent or fixed-repayment systems affect the net returns of education, since the larger remission rate in income-contingent systems implies larger costs for governments but larger benefits for students. Among OECD countries, Turkey, with 1-2 years, has the shortest loan repayment period. Hungary, the Netherlands, the UK and to a certain extend the USA (who uses a mixed system) are among the few countries who use the income-contingent system with a minimum of a 9 year repayment period.

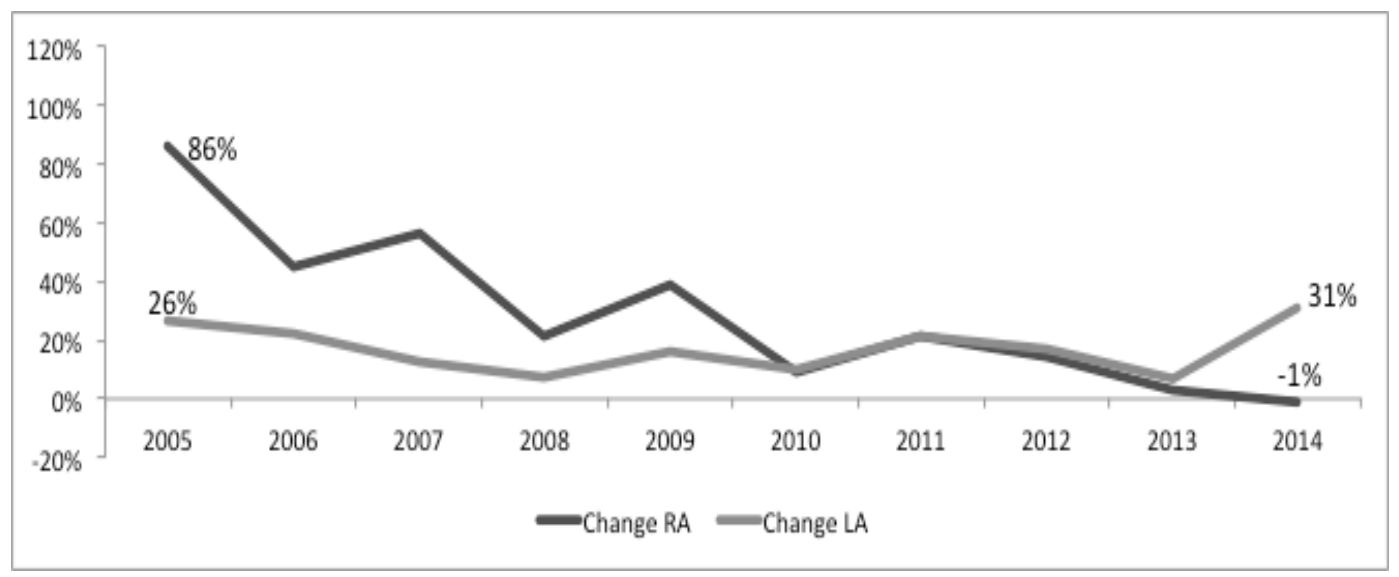

Figure 1. Increase/ Decrease in total loan and repayment amounts

Notes: "RA" and "LA" refer to repayment amounts and total higher education student loan amounts, respectively. 
According to the 2014 annual report of the Turkish Higher Education Credits and Dormitory Institution "KYK" (YURTKUR, 2014), the amount of monthly higher education loans per student distributed at undergraduate, masters and PhD level in 2014 are TL 280, TL 560 and TL 840, respectively. An analysis of the historical repayment amounts of the total loans (contribution fee loans, which are suspended starting 2012, and higher education loans), shows a discernible downward trend from $86 \%$ in 2005 down to $-1 \%$ in 2014 as depicted in Figure 1. Although the total loan amount distributed to students has increased from TL $628 \mathrm{mn}$ in 2004 to almost TL $3 \mathrm{bn}$ in 2014, the repayment amounts as of 2014 are around $30 \%$. These findings indicate that, on average, a student can repay only one third of her debt to the state and that the situation has been worsening in historical perspective. Currently, close to a million students in Turkey who have defaulted on their student debt from the last 10 years have received a collection letter from the tax authority.

In the USA, the current national default rate on student loans made by government fell to $11,8 \%$ from last year's 13,7\% based on 620.000 borrowers whose loans first became due during the 2012 fiscal year. Reportedly, the slight drop in default rates is credited to the success of getting more borrowers sign up for income-based repayment plans (Stratford, 2015).

Research suggests that, unemployment increases the likelihood of default, making success in the job market critical to repaying student loans and manageability of monthly payments is highly correlated with default (Dynarski, 1994). Lower rates of default also seem to be related to the positive effects of a loan counseling or consumer education program (Seifert \& Worden, 2004; Steiner \& Teszler, 2005).

\section{Alumni and Voluntary Giving}

In the USA, charitable contributions represent a significant portion of funding for higher education. In 2014, voluntary support for higher education amounted to USD 37.45 billion, where the highest portion of donations with $29,9 \%$ and $26,3 \%$ from foundations and alumni, respectively. It is also worth mentioning that $17,4 \%$ came from nonalumni. The top fundraising institutions raised $28,6 \%$ of all gifts to US higher education institutions, among them Harvard University and Stanford University with USD 1.16 bn USD $928.46 \mathrm{mn}$, respectively, being the highest fundraisers. Rescuing funding through alumni is a tedious task involving allocation of resources such as university personnel. Moreover, it takes a long time for a university to establish network of dedicated alumni willing to contribute in monetary terms and also spread the word to their own network. Alumni can be irritated by unsolicited calls from a alumni office representative asking for money and offering not much in return. According to the Voluntary Support of Education (VSE) survey, despite the increase in amounts of alumni contributions, participation rates declined to $8,3 \%$ in 2014 from $8,7 \%$ in the previous year (CAE, 2015).

Keniston (2014), interpreting the findings of Eduventure's Alumni Pulse Research on more than 70.000 alumni responses, contrasts the markable difference in motivations between the boomer and Millenials generations. Where $50 \%$ of boomers (individuals born in post-World War II period) cite "obligation" to be a primary motivator to give, this percentage declines to $27 \%$ for Millenials, who are more likely to be motivated by the impact that they believe their gift will make.

Carkoglu (2006), maintains that the act of giving in Turkey appears to be motivated mainly by religious obligations (32\%), traditions and customs (26\%). A sense of obligation to serve society $(12 \%)$, and expectations from society to give $(9 \%)$ are found to be less significant factors. In terms of obligations to help the needy, individuals attribute most responsibility to the government (38\%) and wealthy individuals (31\%), as opposed to themselves or civil society organizations. Individuals display a strong preference for direct, individual-to-individual-giving and consider this to be the most effective mode for eliminating economic and social injustices. 
According to the Charities Aid Foundation World Giving Index 2014 Report, among charity giving countries the USA ranked highest, with a $64 \%$ giving score whereas, Turkey, ranked 128th, with a giving score of $18 \%$. The Index provides a three dimensional breakdown of charitable giving in the form of giving to charity, volunteering time and helping a stranger. Turkey ranked 112, 132 and 106, respectively, on these dimensions (CAF, 2014). Pickering (2015), offers as a possible explanation for Turkey's low rakings, that Turkish people prefer to give informally or the unfavorable way tax incentives are structured, with a 5\% cap placed on annual taxable income is not really inducive to giving. Another potential reason the author conjectures, is that Muslims may prefer to contribute through religious organizations in the forms sadaka and zakat.

Unfortunately, there is no centralized public data in Turkey with detailed information on alumni giving available. Only piecemeal, self-reported and volunteered information such as the information on "BUVAK", Turkey's prominent Bogazici University's (BU) Foundation can be obtained through web research. BU's alumni association as of 2009, reportedly had 45.000 alumni out of which were 14.000 members and 7.000 of them were fee-paying. 500 alumni graduated yearly and around 300 of them became members by paying the required one-time entrance fee. The membership ratio of $30 \%$ is said to be the highest rate in Turkey and compares with that of Harvard University (Zihnioglu, 2010). According to BUVAK's 2014 annual report (BUVAK, 2014), 62 scholarships were created through donations amounting to a total of TL $5.2 \mathrm{mn}$ as of 2014. With charity campaigns during 2014, a total of about TL $2 \mathrm{mn}$ has been contributed by alumni, Bogazici friends and other persons and institutions. At Sabanci University's alumni website, it is reported that $25 \%$ of operational expenses are covered through institutional and private individual donations, $70 \%$ through tuition revenue, and the remaining $5 \%$ with other revenues.

As opposed to Turkey, there are established systems of planned giving in the USA, where alumni can contribute to an endowment fund while simultaneously helping the schools and getting tax reliefs and interest payments. As an example, the 20-year charitable lead annuity trust at Harvard, as explained in the University's Gift Strategies Newsletter (Harvard University, 2009), is a contractual agreement between Harvard and the donor that offers a tax-advantaged way to secure income during retirement. In exchange for contributing cash, securities or property, the donor receives a fixed quarterly payment during their lifetime that is backed by the assets of the University.

While collecting giving statistics and theorizing on why alumni give or don't give is beyond the scope of this paper, an analysis of websites of universities in the USA and Turkey provides informative insights. The main determination of such is that Turkey, indeed is at a different stage of realizing the importance of alumni giving. Where, the USA is worrysome about falling donation rates, and both the US academia and the practioners focus on how to elevate these rates, Turkey doesn't seem to be too much aware of the potential power of this untapped, dormant source.

Apart from other differences, what is evident is that alumni relations and ways of solicitation differ drastically when Turkey and the USA are compared, with lessons to be learned from the latter. As an example, where BU has a simple website (http://www.buvak.org.tr/bagis.php) and an electronic form providing a couple of donation options (to a scholarship fund, the scholarship pool, Hamlin Hall, etc.) including pull down menus containing additional information upon selection of an option, Harvard has a professionally administered, eloborate system operating successfully for decades. Nevertheless, BU, is one of the pioneers in Turkey in organizing their alumni network effectively with annual reports of operations published on their website in a transparent way. 
Table 1a. Fundraising Websites of Selected Public Universities in Turkey

\begin{tabular}{lcccccc}
\hline University & BU & ODTU & ITU & Dokuz Eylul & Akdeniz & Dicle \\
\hline Location & Istanbul & Ankara & Istanbul & Izmir & Antalya & Diyarbakir \\
Est. & $1863 / 1971$ & 1956 & $1773 / 1944$ & 1982 & 1982 & 1974 \\
www & $\mathrm{Y}$ & $\mathrm{Y}$ & $\mathrm{Y}$ & $\mathrm{Y}$ & $\mathrm{N}$ & $\mathrm{N}$ \\
F1 & 2 & 2 & 1 & 2 & 0 & 0 \\
F2 & 2 & 2 & 1 & 2 & 0 & 0 \\
F3 & 2 & 1 & 2 & 0 & 0 & 0 \\
F4 & $\mathrm{Y}(2012 / 13 / 14)$ & $\mathrm{N}$ & $\mathrm{N}$ & $\mathrm{N}$ & $\mathrm{N}$ & $\mathrm{N}$ \\
\hline
\end{tabular}

Table 1b. Fundraising Websites of Selected Foundation Universities in Turkey

\begin{tabular}{lcccccc}
\hline University & Bilkent & Koc & Sabanci & Izmir Ekonomi & Baskent & Hasan Kalyoncu \\
\hline Location & Ankara & Istanbul & Istanbul & Izmir & Ankara & Gaziantep \\
Est. & 1984 & 1992 & 1994 & 2001 & 1994 & 2008 \\
www & $\mathrm{Y}$ & $\mathrm{Y}$ & $\mathrm{Y}$ & $\mathrm{N}$ & $\mathrm{N}$ & $\mathrm{N}$ \\
F1 & 1 & 2 & 2 & 0 & 0 & 0 \\
F2 & 2 & 2 & 2 & 0 & 0 & 0 \\
F3 & 2 & 1 & 2 & 0 & 0 & 0 \\
F4 & Y (2005-2014) & $\mathrm{N}$ & $\mathrm{Y}(2006-2012)$ & $\mathrm{N}$ & $\mathrm{N}$ & $\mathrm{N}$ \\
\hline
\end{tabular}

Notes: "www" refers to whether a separate website is present that is specifically geared towards alumni contribution. F1-F4, refer to website features, where "F1" is ease of access and donating, "F2" is user friendliness, "F3" is detail and transparency and "F4" is existence of feedback in the form of a separate annual report. The scoring is on a $0-2$ scale where, 0 is not available, 1 is average, and 2 is best, according to the benchmark university in the respective category. $\mathrm{Y} / \mathrm{N}$ stands for yes/no.

Tables $1 \mathrm{a}$ and $1 \mathrm{~b}$ demonstrate an analysis of selected public and foundation university websites. Among the foundation universities analyzed, Sabanci University's alumni website is elaborate, user friendly and provides detailed explanations of where the donations went. On the other hand, among public universities, BU's alumni website is the most extensive. Apart from the universities located in the big metropolitan city of Ankara, Istanbul and Izmir, neither public nor foundation universities elsewhere in Turkey, don't seem to place much importance, if any, on their virtual presence to attract donations.

Another aspect of alumni relations needs to be underscored at this point. US colleges and universities have higher stakes in attracting alumni giving than just monetary benefits. Publications like U.S. News and World Report include "alumni participation," the percentage of giving alumni each year, in their evaluation formula. The metric is very influential and viewed as a customer satisfaction measure (Michael, 2014).

As for the literature on higher education finance in Turkey, a comprehensive study on devising a financial system resting on alumni contribution facilitated by a crowdfunding platform, income-contingent repayments and a complete organizational governance structure that rests on a interdisciplinary theoretical framework, doesn't currently exist. Even papers studying some aspects common with this study are very limited. For instance, Teker and Teker (2014), propose a repayment plan for a student bank loan that at time of origination, takes into consideration certain metrics related to the students' track records and future financial positions. Caner and Okten (2013), analyzing whether students of different socioeconomic backgrounds benefit from publicly financed higher education in Turkey equally, determine that it is the students coming from higher income and better educated families that are more likely to go to those universities that receive a larger portion of government subsidies. From an economic cost-benefit standpoint, Golpek (2015) analyzes private return rates and the demand for higher education. 


\section{Theoretical Framework}

This paper rests on critical elements derived from behavioral economics and prospect theory. These can be applied to interpreting both, student and alumni behavior. Alumni giving models describing key drivers for giving, active involvement in alumni associations and respective expectations of alumni, complement the underlying theoretical framework of this study.

Decision-making and choice, is such a complex subject that it has created its own discipline, "decision sciences", involving collaborative approaches from diverse disciplines that enable datadriven decision making. Decision making, as is commonly accepted, is thought to be influenced by several factors like age and individual differences, cognitive biases and past experience (Bruin, Parker, \& Fischoff, 2007; Stanovich \& West, 2008; Juliusson, Karlsson, \& Gärling, 2005). Until Simon (1955), brought to attention the limits of rationality, human beings were all considered to be rational decision makers operating under Bayesian rules and principles of mathematics. Simon's concept of "boundedrationality" posits that pure rationality in decision making is impossible since, there is limited capacity of human beings to acquire and store all information that is available, the amount of time to make a decision is not finite, and the information available may be unreliable or restricted. Thus, even if the intention is to make a rational decision, individuals may need to forego optimization or maximization in favor of making satisficing choices.

The decision of obtaining a tertiary degree, the foregone benefits of finding a job after highschool, applying for a loan and managing the repayments coupled with economic constraints, are all situations involving stress and uncertainty under which cognitive biases may be exacerbated, especially when the decision maker is a young person not accustomed to making life-changing, complex decisions.

The pioneering paper in behavioral economics, "prospect theory" (Kahneman \& Tversky, 1979), assumes that human beings may not always be rational decision makers, and when faced with situations requiring action, they have a tendency to revert to heuristics (efficient rules by which people form judgments). These "mental shortcuts" may work well in certain situations but can also result in systematic deviations from rational choice theory producing cognitive biases. Shefrin (2007), defines bias as a "predisposition towards error". The literature review and findings presented throughout this study, suggest that students, as well as alumni, are prone to having cognitive biases.

In general, both the motivations and attitudes underlying student loan defaults and delinquencies and alumni participation, may be explained with heuristics. One of them is loss aversion, which is related to the individual's stronger desire to avoid losses than to experience comparable gains. In other words, the fear of losing is greater than the possibility of gaining. US institutions have already started scrutinizing the underlying reasons for the decrease in alumni participation and recognize loss aversion as a major driver of such. As Michael (2014) explains, once loss aversion as a factor of churning is determined, it is easy to transform alumni relations through simple and systematic touches, such as acknowledgment letters, annual branded tokens of appreciation, thank you postcards from the president, thereby boosting alumni retention rates.

Loss aversion is more acute when the issue is framed in negative terms and the same individuals will make a riskier decision when confronted with a "negatively-framed dilemma" (Rhoads, 1997). While global studies are trying to uncover drivers of alumni giving, recent troublesome declines in alumni giving rates have given rise to a relatively new branch of research on "why alumni don't give". There are studies that argue that the positive experience alumni had as students translates into future donations, and while some researchers attribute positive experience to extra-curricular activities as a student (Hartman \& Schmidt, 1995; Clotfelter, 2001), others find that identification with the college, as a factor associated with giving, occurs in the classroom (Tom \& Elmer (1994). The present study concurs with the vast literature that establishes a positive relationship between student satisfaction and alumni giving. 
While there may be other factors that foster alumni giving, such as being asked, the availability of tax benefits, and a sense of duty, it is argued that the key difference between nondonors and donors occurs during the internalization of their college experiences, which affects the decision-making process of whether or not to make a gift (Van Slyke \& Brooks, 2005). Wastyn (2009), suggests that fundraising must extend its reach throughout the university to help students frame their experience from a non-consumer mentality, effectively engaging them to support their alma mater.

On top of risk aversion, some students are hesitant to borrow for college due to poor prior experiences in the credit market, a cultural aversion to debt, or various other reasons related to having preferences against borrowing (Boatman, Evans, \& Soliz, 2014), all of which can be related to their inclination on relying on a previous unpleasant experience (the "anchoring" heuristic).

Along similar lines, Meer and Rosen (2012), allude to the presence of an "annoyance effect", where alumni resent the fact that they have to repay loans. In a study conducted by Gachter, Orzen, Renner, and Starmer (2009), 93\% of PhD students registered early when the penalty fee for late registration was emphasized, with only $67 \%$ doing so when this was presented as a discount for earlier registration. The framing effect is reported by the authors to have consistently proven to be one of the strongest biases in decision-making.

Finally, in the digital era of constant connectivity, the "herding effect" stands out to have the potentiality to be a main heuristic among students and alumni. Herding is a form of convergent social behaviour that can be broadly defined as the alignment of the thoughts or behaviours of individuals in a group (herd) through local interaction and without centralized coordination (Raafat, Chater, \& Frith, 2009). When acts of alumni giving are made viral by website or email announcements a contagion effect may be produced, leading other alumni to contribute as well. Giving, as previously discussed, can be triggered, by the positive experience alumni had as students or by observing their peers who give.

Hoyt's model (Hoyt, 2004) of the drivers of alumni giving rest on the postulate that alumni need to have attained a certain level of motivation or be pre-disposed towards giving, in the form of investing money and time, work for the alumni association, and have an interest in planned giving.

The theoretical framework clearly establishes that alumni and students are prone to applying similar mental shortcuts when making decisions. In order to establish a sustainable model of increasing revenue streams from alumni and stimulate students' effective engagement in paying back their obligations, all stakeholders must have a positive and motivating experience on an ongoing basis. Over time, the giving cycle then, can become self-reinforcing and may even grow beyond alumni giving, to include donations and systematic giving from nonalumni.

\section{Research Methodology}

Seggie and Bayyurt (2015), argue that researchers need to pay attention to not what people say they are doing, but rather, to what they are doing. This study seeks to understand the higher education problem in association with what the primary stakeholders are, or are not, doing, and, to that end, employs online qualitative data and content analysis. According to Mayring (2014), qualitative analysis encompasses document analysis, observational studies, focus groups and secondary analysis. Data triangulation for validation purposes is achieved through using multiple sources of data coming from secondary analysis, focus group discussions, Eksi Sozluk entries and Google Trends search statistics.

The first step aims at formulating the research questions by determining the main problems related to higher education financing. Based primarily on the global literature review, the author's own observations and analysis of secondary data described previously, associated sub-themes and the scope of this study are determined. 
In this regard, the manifestation is that, quality employment entails quality education, and, providing equal accessibility to quality education necessitates adequate financing. Since in Turkey more than $16 \%$ of the population live below the poverty line with high rates of unemployment, the majority of students have to rely on external funding. However, the state alone can't subsidize the high tuition rates charged by foundation universities, thus, new sources of revenue must be created.

Consequently, the research questions of this study are: (1) what are alternative venues to obtain higher education financing, (2) what, if any, are the biases and motivations of the primary stakeholders involved in higher education finance, and (3) can a model be devised that appeals to systematic shortcomings and stimulates an influx of revenue into higher education while providing incentives towards students' repayment.

The first research question is explored and answered by means of a critical literature review. Both, globally and locally, it is determined that resources allocated from state budgets are no longer sufficient (Kurt and Gümüs, 2015) and, that in order to cover the costs of the growing number of students receiving higher education and the increases in the cost per student, revenue streams to higher education must be diversified (Johnstone, 2009). This determination is also validated by the 2015-2019 Strategic Plan of Turkey's Council of Higher Education ("YÖK"), which draws attention to the increase of the share in non-public sources of funding in higher education globally. Accordingly, creating opportunities to obtain new and diversified revenue sources for higher education next to state funding, is reported to be instrumental towards achieving YÖK's second strategic aim, namely; increasing access to higher education and continued growth (YÖK, 2014). Followed by public institutions as well, private institutions in the USA have pioneered in successfully diversifying their revenue sources, an important part of which has been philanthropic giving and alumni endowments (Jaramillo \& Melonio, 2011). There is an extensive bulk of research on factors that influence alumni giving, the most relevant of which, has been summarized in the Theoretical Framework section of this paper.

The second research question is related to students of higher education institutions and alumni as proposed alternative funding providers. As indicated, due to the relatively long experience of US institutions with regard to alumni funding and philanthropic giving to higher education institutions, a broad spectrum of research exists addressing aspects of financial and non-financial motivations for alumni giving (Van Slyke \& Brooks, 2005) or non-giving (Meer \& Rosen, 2012), and, students attitudes towards borrowing and loan repayment (Boatman et al., 2014). It is this research question that is also explored empirically through three sources of data collection; 1) posts to Eksi Sozluk, 2) search queries through Google, and 3) a focus group, to obtain insight into Turkish students' sentiment. The use of online, as well as traditional data sources, serves towards obtaining a comprehensive understanding of student sentiment in Turkey and strengthening respective findings through data triangulation. The research methodology and related findings are presented in this section. As pointed out by Kurt and Gumus (2015), donations to higher education institutions in Turkey are rather insufficient and appear to be merely one-time actions instead providing a sustainable source of revenue. Thus, to gain an understanding of how Turkish universities utilize one of their most valuable assets, their digital presence, as embodied through their websites, to access potential alumni and donors, a web search of Turkish universities has been done. A sample of findings is reported in Tables $1 \mathrm{a} \& \mathrm{~b}$ of this study.

The third, builds upon the previous research questions and proposes a model (the "A-CSDF Model" described in the following section), which encapsulates and offers potential solutions to relevant issues outlined, such as primary and secondary research findings related to students' sentiment towards borrowing and loan repayment (or the lack of such) presented herein. 


\section{Online and Traditional Sentiment Analysis}

Online sentiment analysis can take the form of analyzing textual data generated through online platforms such as blogs, message boards and social media, and inferring what users are feeling or thinking by the words they are using online. This enables the researcher to determine the subjectivity, polarity (positive or negative) and polarity strength (weakly positive, mildly positive, strongly positive, etc.) of a piece of text (Osimo \& Mureddu, 2012). For instance, Antweiler and Frank (2004) establish that posts on Yahoo! Finance and Raging Bull message boards help predict stock market volatility, while Tumasjan, Sprenger, Sandner, and Welpe (2010) provide empirical evidence that Twitter messages can be considered a valid indicator of political opinion. Similarly, Dhar and Chang (2009), analyze the usefulness of blogs and social networks, as well as reviews in consumer, online media, and mainstream media, in predicting album sales in the four weeks before and after the album's release date. The authors find that the most significant variable is blog chatter or the volume of blog posts on an album, with higher numbers of posts corresponding to higher sales.

Another form of online sentiment analysis that is becoming popularized across disciplines is to explore the information content of web search queries. As explained in Choi and Varian (2012), the pioneer studies that advocate the usefulness of web search data in forecasting macroeconomic statistics (Ettredge, Gerdes, \& Karuga, 2005) and presenting Internet search activity as an innovative tool for passive surveillance of health information-seeking behavior (Cooper, Mallon, Leadbetter, Pollack, \& Peipins, 2005) were followed by studies in epidemiology (Polgreen, Chen, Pennock, Nelson, \& Weinstein, 2008; Ginsberg et al., 2009) that showed that search data could predict the incidence of influenza-like diseases. Da, Engelberg, and Gao (2011) propose the Google Trends search volume index as direct measure for investor attention while Vosen and Schmidt (2011) establish that Google Trends is a very promising new source of data to forecast private consumption, since in almost all experiments conducted the Google Indicators' in-sample and out-of-sample predictive power proved to be better than that of the conventional survey-based indicators.

There are also several examples of studies studying text-based online generated data and aggregate web query results focusing on Turkey. For instance, Yazicioglu and Borak (2012) who use data from Eksi Sozluk, Yahoogroups and Facebook groups, offer insight on how local and global social media and online discussions co-create the meanings surrounding a brand. The authors assert that due to both its textual and contextual diversity when compared with other social media, Eksi Sozluk represents the richest resource in their study. Erhart (2014), quoting sociologist Zeynep Tufekci ("Eksi Sozluk is Wikipedia, a social network, and Reddit rolled into one") analyzes Eksi Sozluk entries, next to Twitter messages, to develop a deeper understanding of soccer fans sentiment. Yakut Ipekoglu (2015) employs content analysis of Eksi Sozluk entries to asses the users' sentiment relating to the words "family" and "kinship" and asserts that social media is an important tool to explore cultural phenomena. Son-Turan (2014), uses Google Trends search queries to assess Turkish investor sentiment towards specific stocks traded on the Borsa Istanbul Stock Exchange and establishes that a relationship is present between Internet search volume and stock return volatility.

When online sentiment analysis (textual, social media analytics, web search query content) is contrasted with traditional qualitative research methods, benefits of the former are that it can speed up and broaden the scope of the process of finding actionable insights and, furthermore, bring to attention issues that the researcher is not explicitly looking for. On the other hand, traditional research methods give the researcher more control over the process of data generation and ability to identify with pre-planned questions the characteristics of the sample. Clearly, online sentiment analysis can provide preliminary ideas and insights which can then be combined with results from offline methods. Through this triangulation process a comprehensive understanding of the issue can be achieved. 
Furthermore Millenials are the first generation that has had access to the Internet in their formative years (Whitehouse, 2014). According to survey results of The Media Insight Project (2015), Millennials consume news and information in strikingly different ways than previous generations, and their paths to discovery are more nuanced and varied than some may have imagined. Millennials also appear to be drawn into news that they might otherwise have ignored because peers are recommending and contextualizing it for them on social networks, as well as on more private networks such as group texts and instant messaging. Accordingly, social media platforms such as Facebook, have become a nearly ubiquitous part of digital millennial life. However, When Millennials want to dig deeper on a subject, search is the dominant method cited by 57 percent, and it is the one cited most often as useful. Moreover, the Wall Street Journal reports that not only are Millenials savvy technology users, but so are their parents (WSJ, 2013), most likely to be Generation X'ers (generally referred to as the people born between 1960s to the early 1980s), who are also closely following the Millenials in their social media usage (The Media Insight Project, 2015). Given the vast array of research findings on the importance of online sentiment data, only a brief summary of which could be provided here for brevity purposes, and given that the scope of this study involves the Internet savvy population, it is intuitive that a sentiment study focusing on Turkey would analyze data generated through two of the most popular platforms: Eksi Sozluk and Google Trends.

Founded in 1999, Eksi Sozluk, with more than 21 million monthly users (Kara, 2015), the collaborative hypertext dictionary representing the biggest online community in Turkey (Yazicioglu \& Borak, 2012), ranks 7th in Turkey and 391st globally in terms of online traffic according to the traffic metric provider Alexa (www.alexa.com). To understand sentiment towards state-provided loans in Turkey, the author has chosen various keywords and subsequently analyzed relevant Eksi Sozluk entries. The keyword search, in this context, that resulted in the highest number of entries was the Turkish translation for "higher education loan", the results of which are reported in the following table.

Table 2. Eksisozluk Queries as Proxy for Sentiment "Higher Education Loan"* Number of Entries and Period: ca. 870 during 2001-2015

\begin{tabular}{|c|c|c|c|c|}
\hline & Positive-Neutral & Radically Negative & Mildly Negative & Informative - Sceptic \\
\hline $\mathrm{F}$ & $5 \%$ & $83 \%$ & $9 \%$ & $3 \%$ \\
\hline RW & $\begin{array}{l}\text { "debt is the whip for } \\
\text { the brave", "spent it } \\
\text { elsewhere", "use now, } \\
\text { worry later", "in for a } \\
\text { penny, in for a } \\
\text { pound", "everyone } \\
\text { takes out a loan, why } \\
\text { shouldn't I?" }\end{array}$ & $\begin{array}{l}\text { “I fool", “Don't you } \\
\text { ever!", “Torture", } \\
\text { “Official usury", } \\
\text { "Nervous } \\
\text { breakdown", } \\
\text { "exploding bomb" }\end{array}$ & $\begin{array}{l}\text { "Can't/ don't want to } \\
\text { "Repayment starts too } \\
\text { early", "Late payment } \\
\text { interest is too high", } \\
\text { "Better alternative is a } \\
\text { bank loan", "The } \\
\text { burden not worth it". }\end{array}$ & $\begin{array}{l}\text { "...interest is too high", } \\
\text { "....penalty payments } \\
\text { will be pardoned", } \\
\text { "what are the } \\
\text { conditions",,"when will } \\
\text { repayment start", } \\
\text { "Received collection } \\
\text { letter, help" }\end{array}$ \\
\hline PC & $\begin{array}{l}\text { Rationalizing, } \\
\text { contemptuous }\end{array}$ & $\begin{array}{l}\text { Resent, hate, disgust, } \\
\text { anger }\end{array}$ & $\begin{array}{l}\text { Desperate, anxious, } \\
\text { regretful }\end{array}$ & $\begin{array}{l}\text { Financially illiterate } \\
\text { confused, distrustful }\end{array}$ \\
\hline
\end{tabular}

*Translated into English from Turkish. " $\mathrm{F}$ ", "RW" and "PC" stand for frequency, recurring wording and predominant connotation, respectively. 
The analysis of the approximately 870 entries on "higher education loan", is summarized in Table 2 and shows that a significant majority of user sentiment is radically negative, in which for example, they describe being fooled into taking out a loan and regret it deeply. There are also many comments on individual feelings of hate and annoyance towards the state for "milking them out of their money" by allegedly charging high penalty rates for late repayments. Delinquency is handled by the Law on the Procedure of Collection of Public Receivables No. 6183. Accordingly, the penalty rates are decided annually by the Council of Ministers. As of October 19, 2010, the monthly penalty rate is $1.40 \%$ accrued on a daily basis. The start date of repayments is two years following the end of the normal study period. The length of the period of the monthly repayment installments is equal to the length of period of the loan payments (YURTKUR, 2014).

Google Trends, with its access to search data from the most popular search engine (Google), is probably the most powerful such tool currently available (Tuffley, 2013). Google Trends is a free service offered by Google, Inc., that analyzes a percentage of Google web searches to identify how many searches were done over a certain time frame relative to a total volume of searches. This data is also made available on a city-wide basis. The indexed search volume data is at weekly frequency and search queries above a certain volume are being included into the query index. The analysis of Internet search traffic may present the opportunity to gain further insight into general trends and patterns in information-seeking behaviour related to higher education loans, both on a country-wide and city-specific basis.

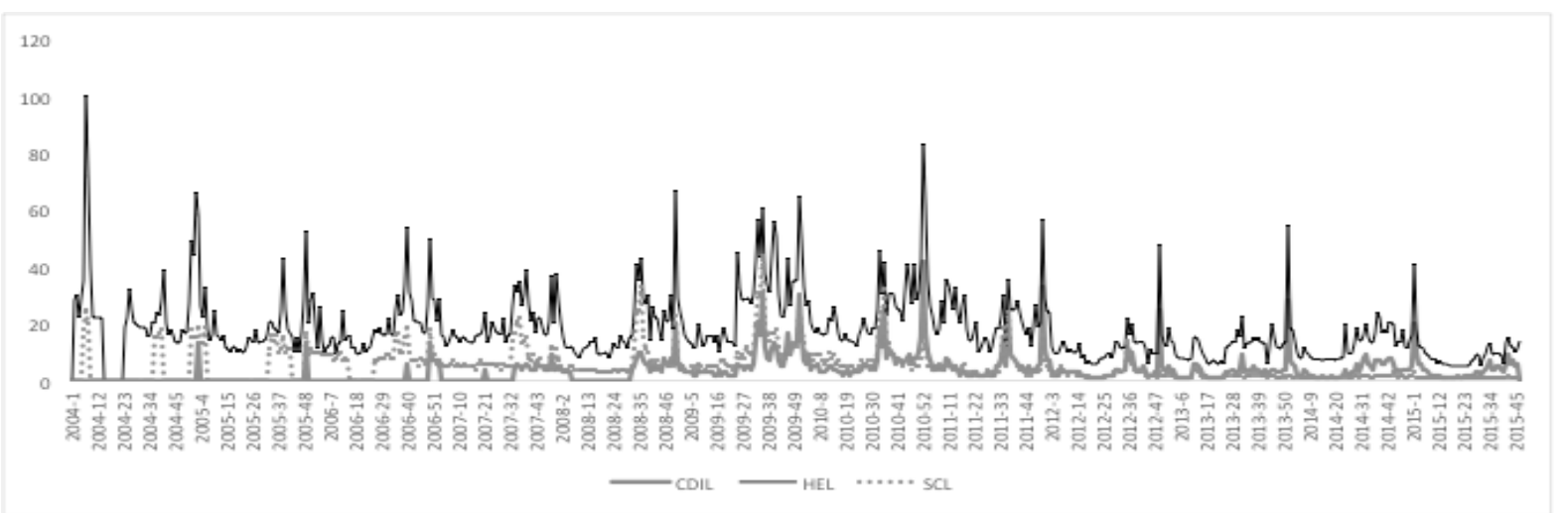

Figure 2. Google Trends Search Volume as Proxy for Sentiment "Credit and Dormitories Institution Loans (CDIL) ", " Higher Education Loans (HEL)", "Student Contribution Loans (SCL)". 2004-2005 at Weekly Frequency * translated into English from Turkish

Figure 2 demonstrates the comparative Google Trends searches for the Turkish translations of "Credit and Dormitory Institution Loans", "Higher Education Loans" and "Student Contribution Loans". There is a declining pattern of interest evidenced by the temporal shortening of the spikes, which may be due to the learning curve effect regarding the difficulties of repayment and the spreading of negative warning signals over Internet (the "herding" effect). Interestingly, when analyzed on a city-wide basis; Sivas, Erzurum, Van and Diyarbakır rank highest in terms of search volume for these three keywords. In contrary, the search for "repayment of CDIL" returned highest frequency search results from the relatively more prosperous cities of Ankara, Adana and Izmir.

Focus groups can be appropriate for obtaining information, generating research hypotheses, stimulating new ideas or concepts, diagnosing problems with or gathering information about services or programs, providing terminology appropriate for the research, and interpreting experimental results (Stewart \& Shamdasani, 2014). The focus group for this study, relies on purposive sampling (Miles \& Huberman, 1994) and consists of eight recently graduated volunteers, who had or had not taken out a student loan in Turkey. The moderator presented items related to this study to determine whether the correct wording and terminology had been used in the online-research stages and understand the drivers of taking on a debt, repaying or neglecting to repay such. The discussion 
validated the appropriate use of terminology and revealed the same thematic categories and similar sentiment as determined by the online sentiment analysis. As such, some of the most prevalent findings are that 1) most students don't "trust" the loan system in Turkey: "I don't trust the KYK" [Participant A], 2) students don't feel an "urge" or even an "obligation" to repay their loans and contemplate putting off due payments in the hope that a pardon may be granted by political parties as part of their electoral campaign agendas. This "sentiment" is more accentuated in debtors or potential debtors coming from less priviledged regions like Eastern Anatolia: "Why should I pay back a loan that is being a created through a fund established with my tax money" [Participant B], 3) there is a discernible "resentment" towards the fact that loans need to be repayed and that funds are not offered for free: "Education should be free at all levels" [Participant C], 4) the process of repayment, penalty interest, and receiving letters from the tax collection agency is said to be "not transparent" in advance and invokes a feeling of arbitrary treatment relying on no clear-cut formal standards, which adds to resentment and distrust towards the loan system in Turkey: "I don't understand how this system works, that's why I'd rather not take part in it at all" [Participant D], and 5) there is common agreement that education and out-of-pocket expenses must be subsidized somehow, especially in expensive metropolitan cities and that authorities should also assist in career-related issues:"Instead of giving us fish and demanding back two fish, authorities should help us to find jobs and be more flexible in terms of repayment" [Participant E].

\section{The A-CSDF Model}

The A-CSDF Model is geared towards addressing all the issues discussed in previous sections and provides a sustainable solution to the student debt problem. The issues identified in this study relate mainly to 1) insecurity with regard to career prospects, 2) the need for funding during higher education, 3) the distrust in the student loan system due mainly to its lack of transparency and the resentment that funds are not "free", and 4) the seemingly unclear repurcussions of default and delinquency coupled with financial illiteracy overall. By recognizing that graduate career, for most students, starts already below the break-even point (where expenses exceed income), an intricate system necessitates auxiliary structures, that assist the students during both, their education and career.

The framework of the A-CSDF Model can be thought of as a cube as illustrated in Figure 3. The A-CSDF Model is designed on functional pillars involving auxiliary structures (mentorship office), supervision (supervision board with compliance, investment and relations committe representatives and performance tracking committee), decision support units (selection, allocation and investment committees), the crowdfunding " $\mathrm{C}-\mathrm{F}$ " platform as digital facilitator, a crowdfunded debt instrument and the two imminent stakeholders (alumni and students).

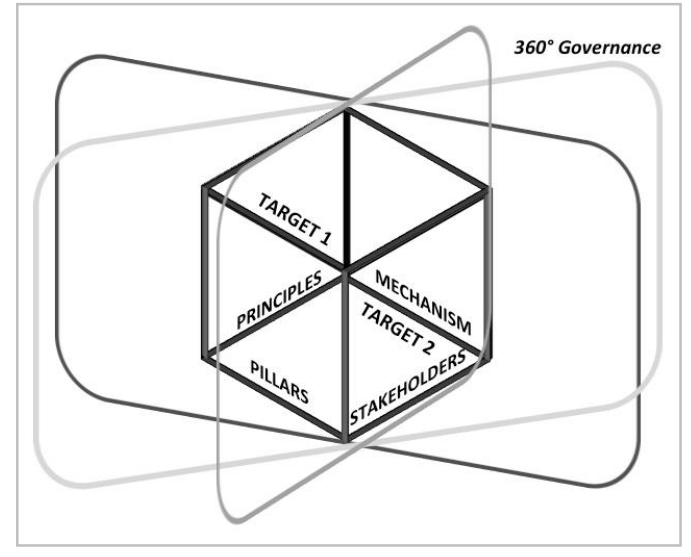

Figure 3. The A-CSDF Framework 
Direct and indirect stakeholders are alumni, students, university, C-F platform provider, the Council of Higher Education and the KYK, regulators, households, alternative lending institutions.

Targets can be grouped according to whether the A-CSDF Model addresses them directly or there are mere outcome of the model. Primary targets are equitable access to quality education, democratizing finance, efficient debt management, increased accountability fostered through financial literacy, an increasingly qualified workforce and effective employer - employee matching services. Secondary targets are an increase in foundation university enrollment rates, contributing to university autonomy, provision of a systematic and transparent setting for philantropic giving and socially responsible investing, support for new forms of financial institutions and alternative venues to stimulate business environments and support entrepreneurs, a gradual increase in economic welfare, enhance university reputation and aid in marketing campaigns during university "open days", and foster stronger alumni networks.

The principles involve ethics, good corporate governanance, participatory oversight, timely response (reward and punishment), optimum performance formulated as a positive-sum game, social responsibility, simplicity, self-supporting sustainability, transparency and mutual accountability, meritocracy, efficiency, respectful competition, equity, mediation (feedback, consulting, educating) and shared values. It relies on behavioral economic principles in its design and implementation to circumvent both, alumni and student biases and to urge students to be responsible in their debt management, which will instill in them a desire to get a job quickly and sustain it so that other students can benefit from the A-CSDF. The mechanism of the A-CSDF relies on a seamless flow of the interactions of pillars and direct stakeholders based on the outlined principles towards achieving the targets.

In line with Tierney's (2001) ideas of creating structures that must adapt and be responsive to the times in which they work, this model, that is essentially, a decision-making mechanism, is adapted and responsive to the needs and motivations of multiple stakeholders. It can be cultivated further through sustainable innovation. As a natural extension of its framework of continuous connnectivity, shared responsibility and commonly agreed upon goals that are supervised by bodies of equal shareholder representation, the A-CSDF Model is enhanced through a 360 degrees governance structure.

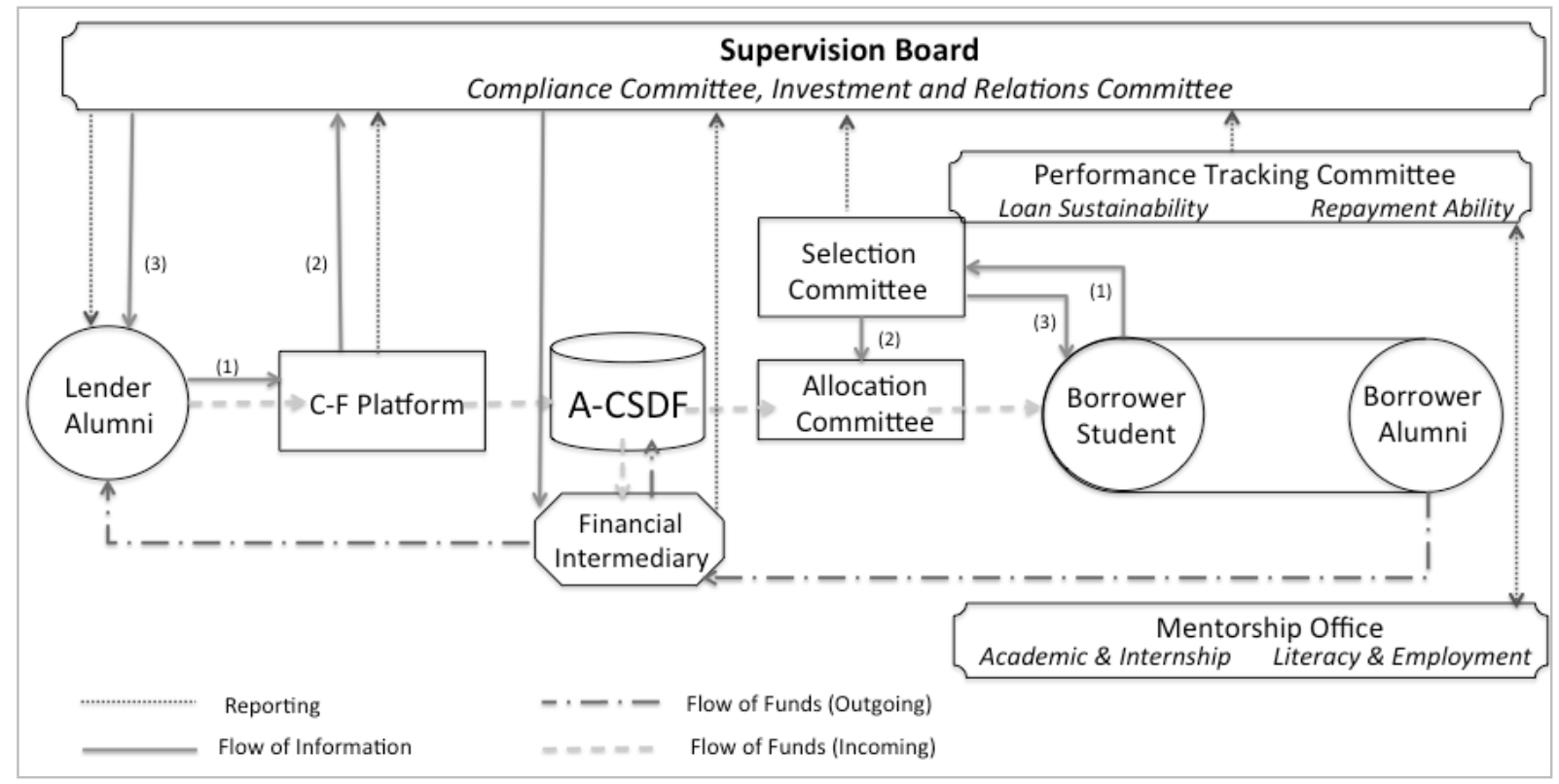

Figure 4. The A-CSDF Model 
The practical application of the model is as shown in Figure 4. The student applies to the selection committee through a written form and a face-to-face interview. If the student satisfies predetermined admission criteria, the selection committee notifies the student and the (funds) allocation committee of the terms, the portion of debt (and the possible, if any, amount of merit-based scholarship that is contingent upon loan origination). According to Marr, Mullin, and Siegfried (2005) adding a scholarship to a loan-only package may increase the likelihood of a subsequent contribution. The student aid/ loan approval procedure has key features that involve academic merit, financial need, coming from a disadvantaged region, or having a disability.

The performance tracking committee tracks the student performance once the student has entered the system. It is composed of two separate units: loan sustainability and loan repayment ability. The loan sustainability unit tracks the students academic and disciplinary performance and updates the supervisory board on a periodic basis. This unit is reponsible for ensuring that the loan can be sustained by the student, i.e., the student meets maintanence criteria. If not, the loan payments could be cut but the student will remain in the system until she has paid off the loan entirely. The loan repayment ability unit comes into effect once the borrowing person switches from student status to alumnus status. The unit tracks whether the student's repayment term has started (which is incomecontingent with an income threshold amount that foresees a $5 \%$ of the debtee alumnus' salary while allowing him to cover all living expenses. This committee also addresses Eksi Sozluk findings provided in Table 2, that presents frequently quoted expressions like "repayment starts too early", "late payment interest is too high", "better alternative is a bank loan". This committee, may offer potential solutions to the debtors in the form of restructuring their loans or providing refinancing alternatives instead of simply leaving them no options but to default on their loans. Chapman (2006) argues that the most important aspect about an income contingent loan is that if the borrower's circumstances are adverse in a particular period, no loan payments are required. This is said to result in insurance, providing both default protection and consumption smothing. To this end, the performance tracking committee is in continuous interaction with the mentorship office that dedicates a mentor to the debtee who provides counseling on academic, job search, employer-employee matching, financial literacy and debt management matters. The mentorship office of the A-CSDF Model, may address and remedy the sentiment signalling financial illiteracy, revealed through expressions, as presented in Table 2, such as "what are the conditions?","when will repayment start?", "received collection letter, help".

On the alumni side, there are two ways to entry into the system: One is by contract, whereby the debtee student becomes a debtee alumni, promising contractually during loan origination, to be in regular interaction with their mentor. Consequently, once debtee alumni fulfill relevant criteria for the inception of the repayment, a certain amount of their wage is withheld and directed towards repayment of capital and interest. A portion of these repayments are funnelled back into the A-CSDF. After the debtee alumni has fully repayed their loan, they become friends of the A-CSDF system promising to contribute in-kind or volunteering donations or assistance. An alternative way of entry into the system, especially in the beginning stages of implementation, is through the crowdfunding platforms social networking site that is promoted by student representatives, already existing "originating" volunteer alumni and the university. Like Facebook, the A-CSDF page is not only geared towards soliciting funds from alumni but rather to offer them a setting where they can exchange ideas, meet former classmates, look up student profiles who are benefactors of the system and track their performance, interests and communicate with them directly through an online forum. 
Once the alumnus registers to the site, he has to specifically indicate his interest in being a debtor. The fundraising feature of the site will be structured in a way that the product will create its own demand because alumni will seek to obtain a reward, to fulfill a need to help, gain a tax advantage by donating, or gain recognition through the visibility feature that accumulates points (or hearts or graduation caps) each time a donation/loan payment is made. Furthermore, alumni have two options for monetary contribution: in the form of donation or in the form of lending. Donating alumni will still receive some non-financial reward once they have reached a certain donation threshold. If they choose the financial reward option, they will receive a promissory note with information on coupon payments and maturity of the loan. All the cash inflows coming from originating alumni and debtee alumni are crowdfunded, however, only a part of these is included in the allocation committee's budget to be loaned out as debt (and scholarship). The remaining portion, is channelled through the investment committee to a financial intermediary, who invests the funds according to a regularly monitored and supervised investment allocation scheme to ensure that enough funds accumulate to repay those alumni holding promissory notes.

\section{Significance and Implications}

\section{Significance}

The A-CSDF Model is a substantial finding because it is based on the premise of behavioral economics, acknowledging the limits to human rationality, and, thereby addressing and circumventing the potential biases of all direct stakeholders. It is implementable in Turkey and in other countries as well, because the issue is even more pressing for developed countries, such as the USA, where Americans' outstanding student debt is higher than all other types of non-mortgage debt. As discussed in the literature review, in the USA student loan default is a growing problem. Alumni giving, which next to foundation donations, is the highest source of revenue for US universities, is declining in terms of participation. The A-CSDF Model has the potentiality to provide a sustainable solution to both aspects to this problem.

As mentioned previously, a common assumption for why individuals prefer direct giving may be attributable to the lack of trust in the institution. Visibility, periodic reporting coupled with the security of having a alumni/lender respresentative present in all committees, units, and the supervisory board and all stakeholders being able to access a wide range of information, enhances transparency. All these features contribute to trust formation.

Each potential motivation driver is framed carefully to encompass all direct stakeholders' cognitive biases, needs and demand, which is one of the strengths of the model. Students or alumni, who have anchoring biases because they may have a bad experience with a loan and with charitable giving, have the opportunity to form anew positive experiences through a contribution system that not only has a financial purpose, but also, aims at fulfilling various social functions. Moreover, as referred to in the literature review (Carkoglu, 2006), Turkish individuals prefer direct giving, thus a peer-to-peer (debt)-based crowdfunding system may trigger their willingness to give.

\section{Implications}

The A-CSDF Model, with its self-reinforcing financing rationale, has the potential to extend higher education beyond major metropolitan cities, by providing equitable access, consequently leading to increased enrollment rates, and, in the long-run, to an increase in the quality of human capital. The well-structured governance mechanism and elaborate framework will provide insurance against student loan default, delinquencies, drop-outs and encourage fair and merit-based competition that is visibly rewarded through the social network interface of the model. The model will also contribute to the autonomy of universities since these will be able to increasingly rely on their own network for financial support. Also, it will serve as a marketing tool for universities, who mobilize huge resources to try to reach out to different regions in Turkey and present themselves. If supported through regulations and given considerable tax incentives, the contributing network may expand to include nonalumni, who give and actively engage on a regular basis, developing loyalty. 
The use of relatively unbiased online data and data triangulation through offline and online resources will surely receive more attention in academia. Using online data and analyzing it through big data analytics tools, like those provided by Google Trends, can enable the researcher to gauge human sentiment in advance of the action. It also provides information on regional searches, as demonstrated in the research methodology section.

The big behavioral data generated from the real-time operations of the model, will not only benefit university administrators in successfully framing all future projects, but also researchers in the fields of education, finance and social economics to further investigate realistic funding projects.

\section{Discussion, Conclusion and Suggestions}

Succinctly explained in Kurt and Gumus (2015), it is not only Turkey who relies on public funds in higher education, but also EU member states, which reportedly cover roughly $70 \%$ of their higher education costs through public funding. As implied, universities have no established culture of sustainable and transparent reporting with regards to the spending and allocation rationale of the portion of public funding they receive. Systemic shortcomings of universities' financing processes, the lack of respective performance measures, such as academic success of students who have received funds and the impossibility to centrally determine the loan repayment efficiency of graduated students, can also be partially inferred from the determinations made in the Credit and Dormitories Institution "KYK" Audit Report prepared by the Turkish Court of Accounts (Saysştay Denetim Raporu, 2015). An important finding in the report, underscoring the system's shortcomings, is that the central student loan system has continued to distribute loans to individuals, who had already lost their student status, and that such erroneously distributed payments, and their legal interest, have not yet been started to be collected. In defense, the KYK reportedly stated that the respective public and private higher education institutions have not provided up-to-date information to the institutions regarding change of status of these individuals, and that the higher education regulation is not explicit as to how the repayment plans for these special situations should be arranged. This problem is more thoroughly recognized in the USA, where the growing student debt is compared to a time bomb that threatens to blow up the entire economy (Berman, 2016). Possible reasons that literature on the financing and debt repayment problem with a focus on the situation in Turkey is relatively limited, compared especially to the USA-originated studies, might be that the problem is not yet immediately recognized, or there are other education priority areas such as the rate of return to and the price of higher education (Golpek, 2014) and gender parity issues (Gumus \& Gumus, 2013).

This study proposes the evaluation of alumni funding as possible solution to the issues related to higher education financing in Turkey. Secondly, the attitude of individuals in higher education towards student loans through primary and secondary research is presented. Lastly, a potentially sustainable model, that could answer systemic and practical shortcomings and sentiment-related biases of both students and alumni, as well as assist in filling the gap of raising a motivated, financially literate, responsible and skilled workforce, is conceptually developed. The alumni websites analysis in this study shows that there is more potential to tap into an underutilized resource, especially in a culture where giving to the needy is valued. Focus group discussions and online content analysis, however reveal the high degree of distrust towards state loans, mainly because no clear and up-to-date information was made available on a regular basis. 
Carefully structured and tailor-sized models like the A-CSDF, may cultivate a deeper sense of belonging, through both, financial and non-financial involvement, and can eventually lead to a cultural shift towards a mutual trust-based community-style way of living through egalitarian cocreation. This could potentially offer a solution to the common finding that emerged from both, online sentiment analysis and the focus group study: the lack of trust in the loan system. This is further fostered by a financial and social network providing predefined and various material rewards and non-material rewards, such as a stream of fixed interest payments, tax incentives and many opportunities for social identity gratification, information exchange, network formation, as well as, socializing opportunities. The A-CSDF Model relies on an innovative alumni engagement strategy, like using a social network to provide feedback on student's performances and make announcements of donations. Through visibility (if they don't opt for giving anonymously) and social recognition, more alumni will want to be a member of "the club", where they can proactively participate to make a change in somebody else's life. Through the performance tracking feature on each student's profile, alumni will be able to obtain instant feedback on how the student is doing or indicate an interest to add or upgrade his scholarship. This model, different from traditional alumni solicitation campaign rationale, does not operate on the premise that alumni owe their alma mater, and instead, has as its motto "share and cultivate".

Ideally, models like the A-CSDF Model could potentially influence various layers of society, and even change the lives of underpriviledged households. Employer alumni may eventually recruit A-CSDF Model participant students, whom they have closely observed throughout their education and gotten to know better than any multi-stage interview process would have enabled them to.

While promising to deliver multiple benefits, the A-CSDF is still at its design stage. To be able to comment on broad implications and present concrete results, a prototype study is suggested to be administered at one of the universities were alumni loyalty is present to a certain degree, since the inception of the system relies heavily on existent originating alumni.

Like it is the case in the USA (Morse and Brooks, 2015), alumni giving in Turkey, may soon be recognized as a student satisfaction metric and those schools, that can collaborate with their alumni, will contribute to their reputation and add value to the degrees they are offering. As alumni motivation and perception has gained wide attention in the global literature, so too should Turkish academicians study this topic and work towards uncovering potentially different cultural drivers of alumni giving.

\section{Acknowledgments}

I would like to thank the organizers and participants of 1. International Higher Education Conference (IHEC) held at Bogazici University on 14-16 October, 2015, for helpful comments on earlier drafts of this paper and to John McKeown for proofreading. 


\section{References}

Antweiler, W., \& Frank, M. Z. (2004). Is all that talk just noise? The information content of internet stock message boards. The Journal of Finance, 59(3), 1259-1294.

Berman, J. (2016, January 30). Watch America's student-loan debt grow \$2,726 every second. Retrieved from http://www.marketwatch.com/story/every-second-americans-get-buried-under-another-3055-instudent-loan-debt-2015-06-10

Boatman, A., Evans, B., \& Soliz, A. (2014). Applying the lessons of behavioral economics to improve the Federal Student Loan Programs: Six policy recommendations. Retrieved from http://c.ymcdn.com/sites/www.ncher.us/resource/collection/DCBD86D9-7685-4DCF-A143A2BF11A0869C/Applying_the_Lessons_of_Behavioral_Economics_to_improve_the_Federal_Poli cy_Loan_Programs.pdf

Bruin, W. B., Parker, A. M., \& Fischhoff, B. (2007). Individual differences in adult decision-making competence. Journal of Personality and Social Psychology, 92(5), 938.

BUVAK. (2014). Faaliyet Raporu. Retrieved from http://www.buvak.org.tr/docs/1429857743_FR_2014__24_nisan_2015_te_gelen_son.pdf

CAE. (2015). Council for Aid to Education Report. Retrieved from http://cae.org/

CAF. (2014). Charities Aid Foundation World Giving Index 2014 Report. Retrieved from https://www.cafonline.org/about-us/publications/2014-publications/world-giving-index-2014

Caner, A., \& Okten, C. (2013). Higher education in Turkey: subsidizing the rich or the poor? Economics of Education Review, 35, 75-92.

Carkoglu, A. (2006). Trends in individual giving and foundation practices in Turkey. Philanthropy in Turkey: Citizens, Foundations and the Pursuit of Social Justice, 95-161.

Chapman, B. (2006). Income contingent loans for higher education: International reforms. Handbook of the Economics of Education, 2, 1435-1503.

Choi, H., \& Varian, H. (2012). Predicting the present with Google Trends. Economic Record, 88(1), 2-9.

Clotfelter, C. T. (2001). Who are the alumni donors? Giving by two generations of alumni from selective colleges. Nonprofit Management and Leadership, 12(2), 119-138.

Cooper, C. P., Mallon, K. P., Leadbetter, S., Pollack, L. A., \& Peipins, L. A. (2005). Cancer Internet search activity on a major search engine, United States 2001-2003. Journal of Medical Internet Research, 7(3), e36.

Da, Z., Engelberg, J., \& Gao, P. (2011). In search of attention. The Journal of Finance, 66(5), 1461-1499.

Dhar, V., \& Chang, E. A. (2009). Does chatter matter? The impact of user-generated content on music sales. Journal of Interactive Marketing, 23(4), 300-307.

Dogan E. (2014). Türkiye'de yoksulluğun ölçülmesi (Dissertation). TC Kalkınma Bakanlığı, Ankara.

Dynarski, M. (1994). Who defaults on student loans? Findings from the national postsecondary student aid study. Economics of Education Review, 13(1), 55-68.

Erguvan, D. (2013). Perceptions of academics towards the impact of foundation universities on Turkish higher education. Educational Sciences: Theory and Practice, 13(1), 153-160.

Erhart, I. (2014). United in protest: From 'Living and dying with our colours' to 'Let all the colours of the world unite'. The International Journal of the History of Sport, 31(14), 1724-1738.

Ettredge, M., Gerdes, J., \& Karuga, G. (2005). Using web-based search data to predict macroeconomic statistics. Communications of the ACM, 48(11), 87-92.

Fuller, A., \& Berkin, D. (2015, September 13). Student debt payback lags. The Wall Street Journal. Retrieved from http://www.wsj.com/articles/student-debt-payback-lags-1442189980

Gachter, S., Orzen, H., Renner, E., \& Starmer, C. (2009). Are experimental economists prone to framing effects? A natural field experiment. Journal of Economic Behavior \& Organization, 70(3), 443-446. 
Ginsberg, J., Mohebbi, M. H., Patel, R. S., Brammer, L., Smolinski, M. S., \& Brilliant, L. (2009). Detecting influenza epidemics using search engine query data. Nature, 457(7232), 1012-1014.

Golpek, F. (2014). Rate of return and price of higher education in Turkey: A case study of law faculty. Education and Science, 39(175), 172-182.

Golpek, F. (2015). Who earnings after four years' education in Turkey: The society or the individual?. Education and Science, 40(177), 19-30.

Gumus, S., \& Gumus, E. (2013). Achieving gender parity in primary school education in Turkey via the campaign called "Haydi Kizlar Okula" (Girls, Let's Go to School). Education and Science, 38(167), 17-26.

Hartman, D. E., \& Schmidt, S. L. (1995). Understanding student/alumni satisfaction from a consumer's perspective: The effects of institutional performance and program outcomes. Research in Higher Education, 36(2), 197-217.

Harvard University. (2009). University's gift strategies newsletter. Retrieved from http://alumni.harvard.edu/sites/default/files/page/files/giftstrategiesspring09.pdf

Hoyt, J. E. (2004). Understanding alumni giving: Theory and predictors of donor status. Retrieved from ERIC databases (ED490996).

Jaramillo, A., \& Melonio, T. (2011). Breaking even or breaking through: reaching financial sustainability while providing high quality standards in Higher Education in the Middle East and North Africa. Washington, DC: World Bank.

Juliusson, E. A., Karlsson, N., \& Gärling, T. (2005). Weighing the past and the future in decision making. European Journal of Cognitive Psychology, 17, 561- 575.

Kahneman, D., \& Tversky, A. (1979). Prospect theory: An analysis of decision under risk. Econometrica, 47(2), 263-292.

Kara, M. (2015, May 5). Sedat Kapanoğlu kurucusu olduğu Ekşi Sözlük'ten ayrıldı. Retrieved from http://webrazzi.com/2015/05/05/sedat-kapanoglu-kurucusu-oldugu-eksi-sozlukten-ayrildi/

Keniston, J. (2014, September 29). Loyalty isn't enough for alumni giving. Retrieved from http://www.eduventures.com/2014/09/loyalty-isnt-enough-alumni-giving/

Kuburlu, C. (2014, July 15). Bedelli ogrencilik. Hurriyet. Retrieved from http://www.hurriyet.com.tr/bedelli-ogrencilik-26808349

Kurt, T., \& Gumus, S. (2015). Trends in financing higher education in the world and recommendations for Turkey. Journal of Higher Education and Science, 5(1), 14-26.

Looney, A., \& Yannelis, C. (2015). Crisis in student loans? How changes in the characteristics of borrowers and in the institutions they attended contributed to rising loan defaults. Brookings Papers onEeconomic Activity, (2), 8.

Marr, K. A., Mullin, C. H., \& Siegfried, J. J. (2005). Undergraduate financial aid and subsequent alumni giving behavior. The Quarterly Review of Economics and Finance, 45(1), 123-143.

Mayring, P. (2014). Qualitative content analysis-theoretical foundation, basic procedures and software solution.

Retrieved

from http://www.researchgate.net/profile/Philipp_Mayring/publication/266859800_Qualitative_conten t_analysis_theoretical_foundation_basic_procedures_and_software_solution/links/543e2a540cf2d 6934ebd0f7d.pdf

Meer, J., \& Rosen, H. S. (2012). Does generosity beget generosity? Alumni giving and undergraduate financial aid. Economics of Education Review, 31(6), 890-907.

Mezza, A., \& Sommer, K. (2015). A trillion Dollar question: What predicts student loan delinquencies? Finance and Economics Discussion Series 2015-098. Washington: Board of Governors of the Federal Reserve System. doi:10.17016/FEDS.2015.098 
Michael, K. (2014, July 14). Fearless Fundraising. Retrieved from http://fearless-fundraising.com/annualgiving/increasing-donor-retention/

Miles, M. B., \& Huberman, A. M. (1994). Qualitative data analysis: An expanded sourcebook. Sage.

Mizikaci, F. (2006). Higher education in Turkey. Monographs on Higher Education. UNESCO/CEPES, Bucharest. Retrieved from http://www.cepes.ro/publications/pdf/turkey.pdf

Morse, R., \& Brooks, E. (2015, September 8). Best Colleges Ranking Criteria and Weights. Retrieved from http://www.usnews.com/education/best-colleges/articles/ranking-criteria-and-weights

OECD. (2014a). Country Note. Retrieved from http://www.oecd.org/edu/Turkey-EAG2014-CountryNote.pdf

OECD. (2014b). Society at a glance 2014 highlights. Retrieved from http://www.oecd.org/turkey/OECDSocietyAtaGlance20142014-Highlights-Turkey.pdf

Osimo, D., \& Mureddu, F. (2012). Research challenge on opinion mining and sentiment analysis. Universite de Paris-Sud, Laboratoire LIMSI-CNRS, Bâtiment, 508.

Pickering, A. (2015, February 26). Why aren't Turkish people giving regularly to civil society organizations?. Retrieved from http://futureworldgiving.org/2015/02/26/why-arent-turkish-people-givingregularly-to-civil-society-organisations/

Polgreen, P. M., Chen, Y., Pennock, D. M., Nelson, F. D., \& Weinstein, R. A. (2008). Using Internet searches for influenza surveillance. Clinical Infectious Diseases, 47(11), 1443-1448.

Raafat, R. M., Chater, N., \& Frith, C. (2009). Herding in humans. Trends in Cognitive Sciences, 13(10), 420-428.

Rhoads, K. (1997). Risky behavior and negative framing. Retrieved from http://www.workingpsychology.com/riskybeh.html

Sayıştay Denetim Raporu. (2015). Retrieved from http://www.sayistay.gov.tr/rapor/kid/2014/Özel_Bütçeli_İdarelerB/YÜKSEKÖĞRENIM\%20KREDİ\%20YURTLAR\%20KURUMU.pdf

Seggie, F. N., \& Bayyurt, Y. (2015). Nitel arastirma. Yöntem, teknik, analiz ve yaklaşımları (1. bs.). Ankara: Anı Yayıncilik.

Seifert, C. F., \& Worden, L. (2004). Two studies assessing the effectiveness of early intervention on the default behavior of student loan borrowers. Journal of Student Financial Aid, 34(3), 41-52.

Shefrin, H. (2007). How the disposition effect and momentum impact investment professionals. Journal of Investment Consulting, 8(2), 68-79.

Simon, H. A. (1955). A behavioral model of rational choice. The Quarterly Journal of Economics, 69(1), 99118.

Stanovich, K. E., \& West, R. F. (2008). On the relative independence of thinking biases and cognitive ability. Journal of Personality and Social Psychology, 94(4), 672.

Steiner, M., \& Teszler, N. (2005). Multivariate Analysis of Student Loan Defaulters at Texas A\&M University. Retrieved from ERIC databases (ED544417).

Stewart, D. W., \& Shamdasani, P. N. (2014). Focus groups: Theory and Practice (Vol. 20). Sage Publications.

Stiglitz, J. E. (2013). Selected works of Joseph E. Stiglitz (Vol. 2). Oxford University Press.

Stratford, M. (2015, October 1). Default rates drop. Retrieved from https://www.insidehighered.com/news/2015/10/01/student-loan-defaults-drop-obama-adminagain-tweaks-rates

Son-Turan, S. (2014). Internet search volume and stock return volatility: The case of Turkish companies. Information Management and Business Review, 6(6), 317-328.

Teker, S., \& Teker, D. (2014). Higher education financing: A proposed model for Turkey. ProcediaSocial and Behavioral Sciences, 116, 849-853. 
TEKSIF. (2015). Kasim 2015 aclik ve yoksulluk siniri. Retrieved from http://www.teksif.org.tr/nisan-2015aclik-ve-yoksulluk-siniri-1334-tl_icerik_10248-1.html

The Media Insight Project. (2015, March). How millennials get news: Inside the habits of America's first digital generation. Retrieved from http://www.mediainsight.org/PDFs/Millennials/Millennials\%20Report\%20FINAL.pdf

Tierney, W. G. (2001). Why committees don't work: Creating a structure for change. Academe, 87(3), 2529.

Tom, G., \& Elmer, L. (1994). Alumni willingness to give and contribution behavior. Journal of Services Marketing, 8(2), 57-62.

Tuffley, D. (2013, April 26). Stock market tip: use Google Trends. Retrieved from http://theconversation.com/stock-market-tip-use-google-trends-13745

Tumasjan, A., Sprenger, T. O., Sandner, P. G., \& Welpe, I. M. (2010). Predicting elections with twitter: What 140 characters reveal about political sentiment. In Proceedings of the fourth international conference on weblogs and social media (pp. 178-185). Washington, DC: The AAAI Press.

TÜIKK. (2015). Gelir ve yasam kosullari arastirmasi. Retrieved from http://www.tuik.gov.tr/PreHaberBultenleri.do?id=18633

Van Slyke, D. M., \& Brooks, A. C. (2005). Why do people give? New evidence and strategies for nonprofit managers. The American Review of Public Administration, 35(3), 199-222.

Vosen, S., \& Schmidt, T. (2011). Forecasting private consumption: survey-based indicators vs. Google trends. Journal of Forecasting, 30(6), 565-578.

Wastyn, M. L. (2009). Why alumni don't give: A qualitative study of what motivates non-donors to higher education. International Journal of Educational Advancement, 9(2), 96-108.

White, A. (2015, March 10). Declining Alumni Giving: What's happening? Why is it happening? And, what can we do about it?. Retrieved from http://givingusa.org/declining-alumni-giving-whatshappening-why-is-it-happening-and-what-can-we-do-about-it/

Whitehouse. (2014). 15 economic facts about Millenials. Retrieved from https://www.whitehouse.gov/sites/default/files/docs/millennials_report.pdf

Worldbank. (2015). Gross enrolment ratio, tertiary, both sexes (\%). Retrieved from http://data.worldbank.org/indicator/SE.TER.ENRR

WSJ. (2013). Mom, stop calling, I'll text you all day. Retrieved from http://online.wsj.com/news/articles/SB10001424127887324354704578636391784495074

Yakut Ipekoglu, H. (2015). Aile ve akrabalık konularındaki sosyal medya paylaşımları uzerine bir degerlendirme. International Journal of Social Sciences and Education Research, 1(1), 293-302.

Yazicioglu, E. T., \& Borak, E. (2012). “A Coke is a Coke?” Interpreting social media anti-brand rhetoric and resolution. Advances in Consumer Research, 40, 561-566.

YÖK. (2014). Yuksekogretim Kurulu Stratejik Planı 2015-2019. Retrieved from http://yok.gov.tr/documents/10279/14571052/yuksekogretim_kurulu_2015_2019_stratejik_plani.p df/0eb5d6db-565b-495e-a470-8823f7e6f6b9

YÖK. (2015). Universitelerimiz. Retrieved from http://www.yok.gov.tr

YURTKUR. (2014). Faaliyet Raporu 2014. Retrieved from http://yurtkur.gsb.gov.tr/Public/Edit/images/KYK/FaaliyetRaporlar1/2014FaaliyetRaporu.pdf

Zihnioglu, E. (2010). Philanthropy and fundraising in Turkey and Bogazici University Foundation.

Retrieved from

http://www.fundraising.at/Portals/0/1_DOWNLOADS/2010/100826_Philanthropy_Fundraising_T urkey.pdf 